\title{
Examination of Size-Dependent Hematological Parameters in Populations of Mauremys rivulata (Testudinata: Geoemydidae) Distributed in Canakkale
}

\author{
Hazal Bilgin \\ Graduate School Of Natural and Applied Sciences, \\ Canakkale Onsekiz Mart University, Canakkale, 17020 Turkey \\ E-mail: hazalblgn@ hotmail.com \\ Cigdem Gul (Corresponding author) \\ Department of Biology, Faculy of Science \& Arts, \\ Canakkale Onsekiz Mart University, Canakkale, 17020 Turkey \\ E-mail: gulcigdem@comu.edu.tr
}

The research is a part of master thesis.

\begin{abstract}
In this study, effect of body size on hematology (erythrocyte count, leukocyte count, mean corpuscular volume, mean corpuscular hemoglobin, mean corpuscular hemoglobin concentration, hemoglobin and hematocrit) and plasma biochemistry (glucose, calcium, cholesterol, triglyceride, creatinin, uric acid, total protein, iron, albumin, phosphorus, magnesium) values of 49 individuals (18 juvenile, 31 adult) belonging to the Mauremys rivulata species dispersed in Canakkale were identified. After transferring to the biochemical tubes which has lithium heparin in it, the blood were taken from the caudal vein of individuals centrifuged for division of plasma. Auto analyzer were used for the values of plasma biochemistry. Other hematologic parameters were defined manually. As a conclusion, reference ranges of hematology and plasma biochemistry values for the species of Mauremys rivulata were determined and effects of body size were established. In comparison to hematology and plasma biochemistry of juvenile and adult individuals, erythrocyte count and calcium levels of juvenile individuals were lower but uric acid was higher when compared to adults. When Pearson Correlation test were used for evaluating the plasma biochemistry values based on body size, there were significant differences between calcium and magnesium and values of calcium and magnesium increased as body size increased.
\end{abstract}

Keywords: Mauremys rivulata, Plasma Biochemistry, Hematology, Changes Based on Size

DOI: $10.7176 / J S T R / 5-4-04$

\section{Introduction}

Defining blood parameters of reptilian species can be a guide for determination of physiological, health and environmental conditions of populations (Jacopson et al., 1991; Pages et al., 1992; Raphael et al., 1994; Dickinson et al., 2002; Lopez-Olvera et al., 2003; Tosunoğlu et al., 2011). There are some internal (species, sex, age and physiological condition) and external (season, temperature, habitat, nutrition, captivity) factors that affect blood parameters of reptilians (Samour et al., 1998; Wang et al., 1999; Dickinson et al., 2002; Peterson, 2002; Gicking et al., 2004; Metin et al., 2006, 2008; Tosunoğlu et al., 2011).

Most of the hematological studies about turtle species include the magnitude and morphological properties of blood cells (Knotkova et al., 2002; Uğurtaş et al., 2003; Metin et al., 2006, 2008; Deem et al., 2006; Colagar and Jafari, 2007). Apart from these studies, there are some studies about hematology and plasma biochemistry in some turtle species (Dessauer, 1970; Dickinson et al., 2002; Knotkova et al., 2002; Tosunoğlu et al., 2005; Deem et al., 2006; Colagar and Jafari, 2007; Hidalgo-Vila et al., 2007; Tosunoğlu et al., 2011). There are not so many studies about hematology and plasma biochemistry in freshwater turtles. Therefore it is important to identify the parameters and to investigate differences between these species beforehand (Tosunoğlu et al., 2011).

The parameters of plasma biochemistry and clinical hematology which belong to the species of Mauremys rivulata were examined and it was determined whether it was influenced by the reproduction period and environmental conditions (Y1lmaz and Tosunoğlu, 2010; Tosunoğlu et al., 2011; Gül et al., 2015). There are some studies to determine whether the body size has an effect on blood parameters in 
different reptilian species (Bolten and Bjorndal, 1992; Fong et al., 2010; Galeotti et al., 2010; Omonona et al., 2011; Scheeling et al., 2011; Hofmeyr et al., 2017; Lopez et al., 2017). But there are not any studies about whether the body size has an effect on the blood parameters and plasma biochemistry of Mauremys rivulata species.

The purpose of this study; is determination of the clinical hematology values (erythrocyte count, leukocyte count, mean corpuscular volume, mean corpuscular hemoglobin, mean corpuscular hemoglobin concentration, hemoglobin and hematocrit) and plasma biochemistry values (glucose, calcium, cholesterol, triglyceride, creatinin, uric acid, total protein, iron, albumin, phosphorus, magnesium), and estimation of whether the body size has an effect on these hematological parameters in the species of M. rivulata.

\section{Materials and Methods}

The province Canakkale which divides Anatolia and Thrace into two continents and having $9.9995 \mathrm{~km}^{2}$ of surface area, locates on the northwest of Turkey. The specimens of the species of $M$. rivulata used in this study were catched from the Dardanos location ( $\left.40^{\circ} 05^{\prime} 25.74^{\prime \prime} \mathrm{W}, 26^{\circ} 21^{\prime} 50.07^{\prime \prime} \mathrm{E}, \mathrm{h}: 1 \mathrm{~m}\right)$ in Canakkale province (Figure 1).

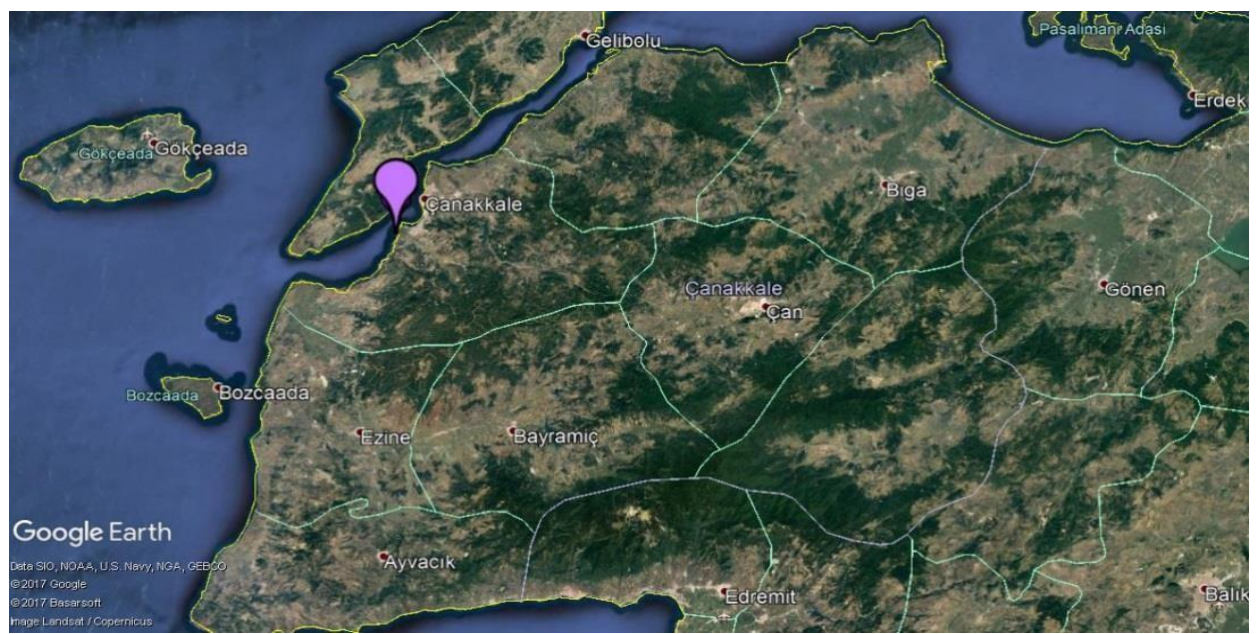

Figure 1. Working Locality ( : Dardanos, Canakkale) (https://maps.google.com)

With the help of gloves, scoop and fyke net; total of 49 specimens including 18 juveniles and 31 adults from the species of $M$. rivulata were captured. Required procedures were applied for the collected specimens by the 2017/ 15247 numbered resolution from the Canakkale Onsekiz Mart University Animal Experimentations Ethics Committee. According to the carapace length (carapace length which is from the anterior tip of the nuchal plate to the posterior tip of the supracaudal plate) of the specimens, which are brought alive to the laboratory, were grouped into juvenile and adult. After the procedures of bloodletting, all of the specimens were carried back to collected area.

According to his study, Ayaz (2003) accepted that the carapace length which is smaller than $10 \mathrm{~cm}$ as juveniles and the ones which are $10 \mathrm{~cm}$ and higher than $10 \mathrm{~cm}$ as adults (Winden and Bogaerts, 1992; Iverson and McCord, 1994).

1-2 ml blood were collected from the dorsal caudal vein of the specimens which are brought to laboratory for hematological and plasma biochemical analyses with 21 gauge needles and $5 \mathrm{ml}$ syringe within the same day (Ballard and Cheek, 2003; Thrall et al., 2004).

Taken blood samples were transferred into the biochemical tubes including lithium heparin in it (dvac) then plasma was separated by centrifugation with Cence 1.500 branded centrifuge machine at $4000 \mathrm{rpm}$ for 10 minutes. After the centrifugation process, studied biochemical parameters (glucose, calcium, cholesterol, triglyceride, creatinin, uric acid, total protein, iron, albumin, phosphorus, magnesium) of divided plasma samples were measured with using commercial kit in ELIMAT S/N 2005 E1001171 branded autoanalyzer. With using Hayem's diluting fluid for erythrocytes and Turk's diluting fluid for leukocytes, were made counting under the microscope (Olympus CX 31) with hemocytometer. With using Sahli technique which is given by Tanyer (1985), hemoglobin was measured by Sahli hemoglobinometer. Utilized standart rates of hematological and plasma biochemistrty values have evaluated by SPSS (20.0 for Windows Student Version) statistics program. The plasma biochemistry values of this species have been compared statistically with using Man Whitney U test in the SPSS program. Parameters which belong to the plasma biochemistry have been searched by the Pearson Correlation test whether they are affected by the body size.

$\mathbf{2 8} \mid \mathrm{P}$ a g e

wWw.iiste.org 


\section{Results}

The species of $M$. rivulata specimens have been identified as juvenile and adult according to the carapace length. Carapace length have been specified as; in juvenile individuals approximately $87.77 \mathrm{~mm}$, in adult individuals approximately $134.89 \mathrm{~mm}$. In this study, the clinical hematology and plasma biochemistry values have been examined that belongs to the juvenile and adult individuals and results of the total number of 19 parameters have been given in the Table 1 .

Table 1. Results of some parameters that belong to the hematologic and plasma biochemistry of juvenile and adult individuals (N: Number of specimens, Min: Minimum, Max: Maximum, SD: Standard

Deviation, RBC: Red Blood Cell Count, WBC: White Blood Cell Count, Hb: Hemoglobin Value, HCT: Hematocrit, MCV: Mean Corpuscular Volume, MCH: Mean Corpuscular Hemoglobin, MCHC: Mean Corpuscular Hemoglobin Concentration)

\begin{tabular}{|c|c|c|c|c|c|c|c|c|c|c|}
\hline \multirow[b]{2}{*}{ Parameters } & \multicolumn{5}{|c|}{ Juvenile } & \multicolumn{5}{|c|}{ Adult } \\
\hline & $\mathbf{N}$ & Min & Max & Mean & SD & $\mathbf{N}$ & Min & $\operatorname{Max}$ & Mean & SD \\
\hline $\operatorname{RBC}\left(\mathbf{m m}^{\mathbf{3}}\right)$ & 13 & 120000 & 470000 & 283076.92 & 110104.84 & 30 & 200000 & 660000 & 385866.66 & 134158.61 \\
\hline $\operatorname{WBC}\left(\mathbf{m m}^{\mathbf{3}}\right)$ & 12 & 1200 & 6000 & 2866.66 & 1280.86 & 30 & 1200 & 6200 & 2676.66 & 1210.49 \\
\hline $\mathrm{Hb}(\mathrm{g} / \mathrm{dL})$ & 12 & 3.20 & 7.80 & 5.25 & 1.24 & 31 & 2.80 & 8.60 & 5.67 & 1.57 \\
\hline HCT (\%) & 15 & 2.00 & 38.00 & 20.40 & 8.55 & 31 & 11.00 & 33.00 & 21.25 & 5.97 \\
\hline $\operatorname{MCV}\left(\mu^{3}\right)$ & 13 & 166.67 & 1500.00 & 760.73 & 424.80 & 14 & 30 & 227.27 & 965.52 & 586.01 \\
\hline MCH $(\mu \mu \mathrm{g})$ & 12 & 114.89 & 412.50 & 211.73 & 82.44 & 14 & 30 & 73.68 & 289.66 & 160.77 \\
\hline MCHC (\%) & 12 & 16.30 & 160.00 & 37.71 & 39.33 & 14 & 30 & 15.15 & 53.33 & 28.12 \\
\hline Glucose (mg/dL) & 13 & 37.99 & 135.70 & 88.84 & 33.61 & 27 & 1.94 & 154.70 & 92.50 & 38.88 \\
\hline Urea (mg/dL) & 13 & 1.20 & 16.30 & 5.90 & 4.90 & 30 & 1.60 & 13.10 & 5.06 & 3.52 \\
\hline Cholesterol (mg/dL) & 10 & 94.67 & 344.50 & 188.11 & 84.90 & 18 & 105.20 & 450.80 & 226.38 & 94.31 \\
\hline Creatinine (mg/dL) & 12 & 0.02 & 0.80 & 0.29 & 0.29 & 24 & 0.01 & 0.98 & 0.37 & 0.29 \\
\hline Uric acid (mg/dL) & 11 & 2.60 & 22.00 & 11.63 & 5.42 & 30 & 0.22 & 21.00 & 7.29 & 6.21 \\
\hline $\operatorname{Albumin}(\mathrm{g} / \mathrm{dL})$ & 14 & 0.31 & 5.19 & 1.44 & 1.21 & 31 & 0.30 & 5.91 & 1.68 & 1.35 \\
\hline Calcium (mg/dL) & 14 & 2.30 & 16.97 & 8.96 & 4.64 & 22 & 5.15 & 21.86 & 14.11 & 3.52 \\
\hline Triglyceride $(\mathrm{mg} / \mathrm{dL})$ & 12 & 11.23 & 110.70 & 55.47 & 38.92 & 22 & 22.03 & 178.40 & 75.53 & 53.32 \\
\hline Total protein (g/dL) & 13 & 0.25 & 5.17 & 2.52 & 1.20 & 30 & 0.64 & 9.61 & 2.55 & 2.00 \\
\hline Phosphorus (mg/dL) & 10 & 0.06 & 2.67 & 1.54 & 0.76 & 26 & 0.16 & 4.90 & 1.46 & 0.92 \\
\hline Magnesium (mg/dL) & 12 & 0.02 & 4.30 & 1.40 & 1.14 & 31 & 0.07 & 15.70 & 2.25 & 2.91 \\
\hline $\operatorname{Iron}(\mathrm{mg} / \mathrm{dL})$ & 6 & 4.70 & 38.10 & 23.35 & 15.14 & 18 & 1.60 & 116.50 & 30.22 & 29.88 \\
\hline
\end{tabular}

Effects of the body size on the hematology and plasma biochemistry have been determined. After the statistical analyses, when compared with the body size; the erythrocyte number, uric acid and calcium parameters have been ascertained that has significant differences statistically. In terms of results of the Pearson Correlation test; a significant positive correlation has been detected between the body size and calcium- magnesium values. 


\section{Discussion}

4.1. Erythrocyte Count

When the erythrocyte count have been compared between the juvenile and adult specimens a substantial difference has been detected statistically ( $\mathrm{P}=0.021$; $\mathrm{U}: 107.5 ; \mathrm{Z}$ : -2.317 ) (Figure 2).

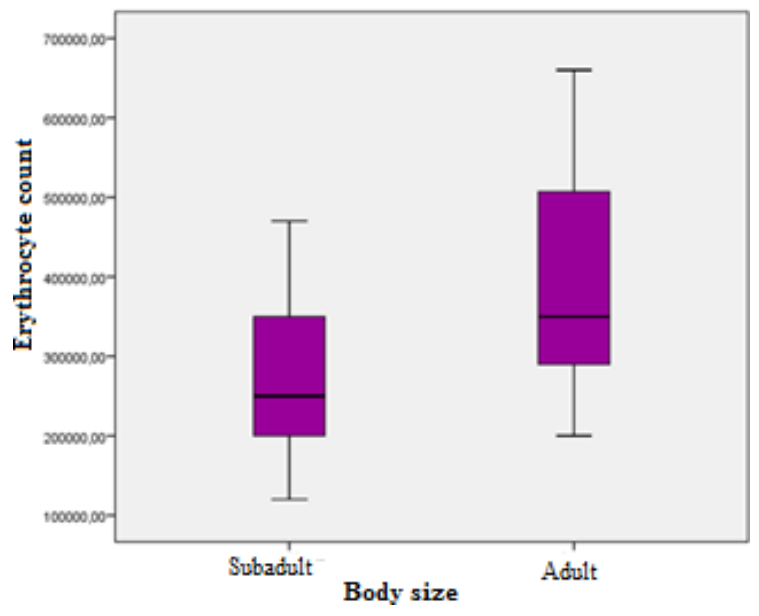

Figure 2. Graphic that shows the erythrocyte count values of the juvenile and adult individuals that belong to the species of $M$. rivulata

When juvenile and adult individuals have been compared with the Pearson Correlation test, a grand correlation has been established between erythrocyte count and body size $(\mathrm{P} \leq 0.05)$. According to the statistical results, positive correlation has been detected, while body size is increasing the erythrocyte count is increasing too $(\mathrm{r}=0.149 ; \mathrm{P}=0.000)$.

The data which are obtained by us about the erythrocyte count are in a harmony with other studies that made with the same species. In the study done by Hofmeyr et al. (2017) about terrestrial turtle (Psammobates geometricus); that juvenile individuals have low erythrocyte counts when compared with the adult individuals have been confirmed, we have been detected that our study has similar results on the species of $M$. rivulata.

\subsection{Uric Acid}

When the uric acid values have been compared between the juvenile and adult specimens a substantial difference have been detected statistically ( $\mathrm{P}=0.021$; U: 86.5; Z: -2.310) (Figure 3).

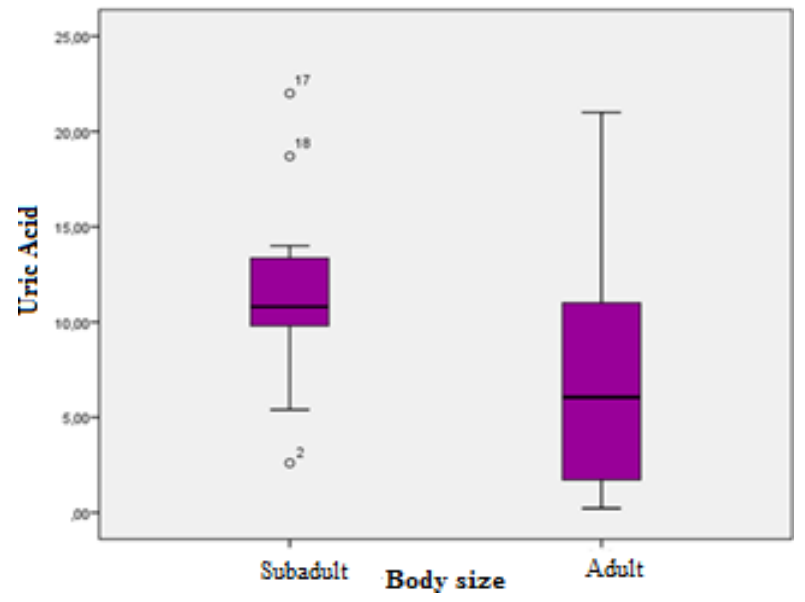

Figure 3. Graphic that shows the uric acid values of the juvenile and adult individuals that belong to the species of $M$. rivulata 
By comparison with the Pearson Correlation test, no significant correlation has been found between the body size and the uric acid values $(\mathrm{P} \geq 0.05)$.

When gender and seasonal differences on previous studies about the turtles have been examined, it has not been encountered a literature about the uric acid changes based on the body size on M. rivulata.

\subsection{Calcium}

When the calcium values have been compared between the juvenile and adult specimens a substantial difference have been detected statistically ( $\mathrm{P}=0.004$; U: 64.5; Z: -2.905) (Figure 4).

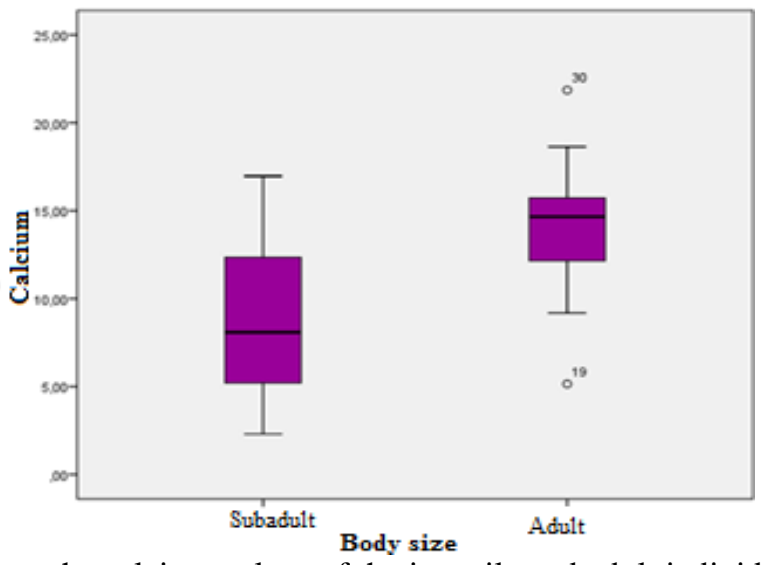

Figure 4. Graphic that shows the calcium values of the juvenile and adult individuals that belong to the species of $M$. rivulata

When juvenile and adult individuals have been compared with the Pearson Correlation test, a grand correlation has been established between calcium values and body size $(\mathrm{P} \leq 0.05)$. According to the statistical results positive correlation has been detected, while body size is increasing the calcium value is increasing too $(\mathrm{r}=0.592 ; \mathrm{P}=0.000)$. In our study, a difference has been detected in point of the calcium value based on the body size, it has not been encountered with a study that compares the calcium values in the juvenile and adult individuals.

\subsection{Magnesium}

When the magnesium values have been compared between the juvenile and adult specimens a substantial difference has not been detected $(\mathrm{P} \geq 0.05)$.

When juvenile and adult individuals have been compared with the Pearson Correlation test, a grand correlation has been established between magnesium values and body size $(\mathrm{P} \leq 0.05)$. According to the statistical results positive correlation has been detected, while body size is increasing the magnesium value is increasing too $(\mathrm{r}=0.338 ; \mathrm{P}=0.027)$ (Figure 5).

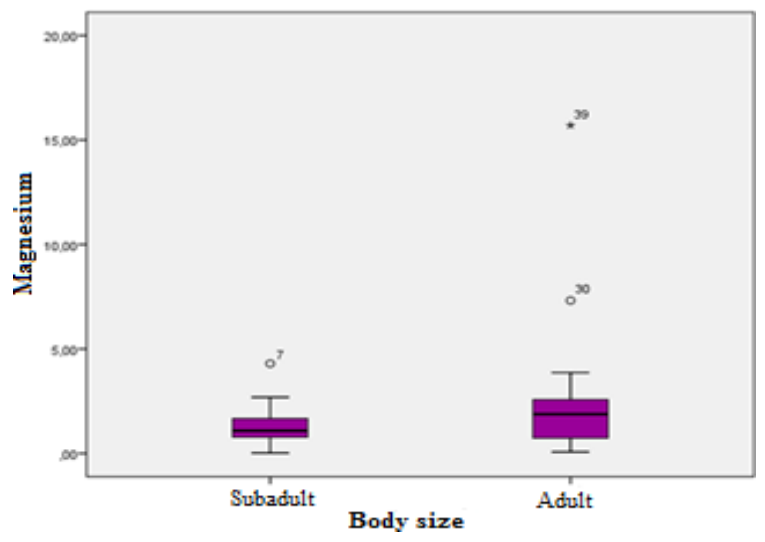

Figure 5. Graphic that shows the magnesium values of the juvenile and adult individuals that belong to the species of $M$. rivulata 
A literature that gives magnesium values of the species of $M$. rivulata has not been encountered. Similar results have been observed with the given values about subspecies of Mauremys caspica leprosa.

Close results have been observed in compared to juvenile and adult individuals in leukocyte number, hemoglobin and hematocrit there have not so many differences.

A significant difference have not been found on the mean corpuscular volume, mean corpuscular hemoglobin, mean corpuscular hemoglobin concentration parameters in compared to juvenile and adult individuals.

It was determined that there was no statistically significant difference between juvenile and adult individuals and there was no correlation based on body size on glucose, total protein, albumin, urea, phosphorus, cholesterol, creatinin, triglyceride and iron values.

Acknowledgments: This study is part of master thesis. A part of this study was presented as a poster in the "VIII. International Symposium on Ecology and Environmental Problems (4-7 October 2017)" and published in the symposium book as a abstract text.

\section{References}

Ayaz D., 2003. Göller Bölgesi ve Doğu Akdeniz Bölgesi Emys orbicularis (Testudinata: Emydidae) ve Mauremys rivulata (Testudinata: Bataguridae) Türlerinin Sistematik Durumu, Morfolojisi, Dağılışı, Üreme ve Beslenme Biyolojisi Üzerine Araştırmalar. Unpublished Doctoral Thesis (in Turkish), Ege University, Izmir.

Ballard B. M., Cheek R., 2003. Exotic animal medicine for the veterinary technician. Blackwell Publishing, Iowa State Press, Ames.

Bolten A. B., Bjorndal K. A., 1992. Blood Profiles for a Wild Population of Green Turtles (Chelonia mydas) in the Sothern Bahamas: Size-Specific and Sex-Specific Relationships. Wildl. Dis., 28: 407-413.

Colagar H., Jafari N., 2007. Red Blood Cell Morphology and Plasma Proteins Electrophoresis of the European Pond Terapin Emys orbicularis. African Journal of Biotechnology, 6 (13):1578-1581.

Deem S. L., Dierenfeld E. S., Sounguet G. P., Alleman A. R., Cray C., Poppenga R. H., Norton T. M., Karesh W. B., 2006. Blood Values in Free-Ranging Nesting Leathherback Sea Turtles (Dermochelys coriacea) on the Coast of the Republic of Gabon. Journal of Zoo and Wildlife Medicine, 37 (4): 464-471.

Dessauer H. C., 1970. Blood Chemistry of Reptiles: Physiological and Evolutionary Aspects. In: Gans, C., and T. S. Parsons (eds.). Biology of the Reptilia, vol. 3. Academic Press, New York. 1$54 \mathrm{p}$.

Dickinson V. M., Jarchow J. L., Trueblood M. H., 2002. Hematology and Plasma Biochemistry Reference Range Values for Free-Ranging Desert Tortoises in Arizona. Journal of Wildlife Diseases, 38 (1): 143-153.

Fong C., Chen H., Cheng I., 2010. Blood profiles from wild populations of green sea turtles in Taiwan. Journal of Veterinary Medicine and Animal Health, Vol. 2 (2) pp. 008-010

Galeotti P., Pelliteri-Rosa D., Sacchi R., Gentilli A., Pupin F., Rubolini D., Fasola M., 2010. Sex-, morph- and size-specific susceptibility to stress measured by haematological variables in captive common wall lizard Podarcis muralis. Comparative Biochemistry and Physiology, Part A 157, 354-363 
Gicking J. C, Foley A. M., Harr K. E., Raskin R. E., Jacobson E., 2004. Plasma protein electrophoresis of the Atlantic Loggerhead sea turtle, Caretta caretta. Journal of herpetological Medicine and Surgery, 14 (3): 13-18.

Gül C., Tosunoğlu M., Hacığlu N., 2015. Some Hametological Parameters of the Mauremys rivulata in Two Different Water Quality in the Biga Stream (Canakkale, Turkey). ICWERC 2015: XIII International Conference on Wildlife Ecology, Rehabilitation and Conservation Paris, FRANSA, 27-28 Nisan 2015, vol.17, no.4, pp. 1960-1962.

Hidalgo-Vila J., Diaz-Paniagua C., Perez-Santigosa N., Plaza A., Camacho I., Recio F., 2007. Hematologic and Biochemical Reference Intervals of Free-Living Mediterranean Pond turtles (Mauremys leprosa). Journal of Wildlife Diseases, 43 (4): 798-801.

Hofmeyr M. D., Henen B. T., Walton S., 2017. Season, sex and age variation in the haematology and body condition of geometric tortoises Psammobates geometricus. African Zoology, 52(1):21-30

Iverson J. B., McCord W. P., 1994. Variation in East Asian turtles of the genus Mauremys (Bataguridae: Testudines), Jour. Herpetol 28: 178-187.

Jacopson E. R., Gaskin J. M., Brown M. B., Harris H. K., Gardiner C. H., Lapointe J. L., Adams H. P., Reggiardo C., 1991. Chronic Upper Respiratory Tract Disease of Free-Ranging Desert Tortoises (Xerobates agasizii). Journal of Wildlife Diseases, 27: 296-316.

Knotkova Z., Doubek J., Knotek Z., Hajkova P., 2002. Blood Cell Morphology and Plasma Biochemistry in Russian Tortoises (Agrionemys horsfieldi). Acta Veterinaria Brno, 71: 191-198.

Lopez J., Ldo. Vet., M. Sc., Waters M., B. V. Sc., M. Sc., Routh, A., B. V. Sc., Cert. Zoo. Med., Rakotonanahary T. F., D.V.M., Woolaver L., Ph. D., Thomasson A., Holmes E., B. Vet. Med., M. Vet. Med., Hanspeter W. Steinmetz, Dr. Med. Vet., Dipl. A.C.Z.M., 2017. Hematology and Plasma Chemistry of the Ploughshare Tortoise (Astrochelys yniphora) in a Captive Breeding Program. Journal of Zoo and Wildlife Medicine, 48(1): 102-115.

Lopez-Olvera J. R., Montane J., Marco I., Martinez-Silvestre A., Soler J., Lavin S., 2003. Effect of Venipuncture Site on Hematologic and Serum Biochemical Parameters in Marginated Tortoýse (Testudo marginiata). Journal of Wildlife Diseases, 39 (4): 830-836.

Metin K., Koca B. Y., Kıral K. F., Koca S., Türkozan O., 2008. Blood Cell Morphology and Plazma Biochemistry of Captive Mauremys caspica (Gmelin, 1774) and Mauremys rivulata (Valenciennes,1833). Acta Veterinaria Brno, 77: 163-174.

Metin K., Türkozan O., Kargın F., Koca B. Y., Taşkavak E., Koca S., 2006. Blood Cell Morphology and Plasma Biochemistry of the Captive Eoropean Pond Turtle Emys orbicularis. Acta Veterinaria Brno, 75:49-55.

Omonona A. O., Olukole S. G., Fushe F. A., 2011. Haematology and Serum Biochemical Parameters in Free-Ranging Africa Side Neck Turtle (Pelusios sinuatus) in Ibadan, Nigeria. Acta Herpetological, 6(2): 267-274.

Pages T., Peinado V. I., Viscor G., 1992. Seasonal Changes in Hematology and Blood Chemistry of the Freshwater Turtle Mauremys caspica leprosa. Comparative Biochemistry and Physiology, 103A (2): 275-278.

Peterson C. C., 2002. Temporal, Population, and Sexual Variation in Hematocrit of Free-Living Desert Tortoises: Correlational Tests of Causal Hypotheses. Cancer J. Zool., 80, 461-470. 
Raphael B. L., Klemens M. W., Moehlman P., Dierenfeld E., Karesh W. B., 1994. Blood Values in Free-Ranging Pancake Tortoises (Malacochersus tornieri). J. Zoo Wildl. Med., 25: 63-67.

Samour J. H., Howlett J. C., Silvanose C., Hasbun C. R., Al-Ghais S. M., 1998. Normal Haematology of Free-Living Green Sea Turtles (Chelonia mydas). From the United Arab Emirates. Comparative Haematology International, 8: 102-107.

Scheeling T. F., Jessop T. S., 2011. Influence of capture method, habitat quality and individual traits on blood parameters of free-ranging lace monitors (Varanus varius).

Tanyer G., 1985. Hematology and Laboratory. Ayyıldız Matbaası A.Ş. Ankara.

Thrall A., Baker D. C., Campbell T. W., De Nicola D., Feetman M. J., Lassen E. D., Rebar A., Weiser G., 2004. Veterinary Hematology and Clinical Chemistry. Blackwell Publishing, Philadephia.

Tosunoğlu M., Tok C. V., Gül Ç., 2005. Hematological Values in Hermann's Tortoise (Testudo hermanni) and Spur-thigted Tortoise (Testudo graeca) from Thrace Region (Turkey). International Journal of Zoological Research, 1 (1): 11-14.

Tosunoğlu M., Yılmaz N., Gül Ç. 2011. Effects of Varying Ecological Conditions on the Blood Parameters of Freshwater Turtles in Canakkale (Turkey). Ekoloji 20, 78, 7-12.

Uğurtaş I. H., Sevinç M, Yıldırımhan H. S., 2003. Erythrocyte Size and Morphology of Some Tortoisesand Turtles from Turkey. Zoological Studies, 42 (1): 173-178.

Wang T., Brauner C. J., Milsom W. K., 1999. The Effect of Isovolemic Anaemia on Blood $\mathrm{O}_{2}$ Affinity and Red Cell Triphosphate Concentrations in the Painted Turtle (Chrysemys picta). Comparative Biochemistry and Physiology Part A, 122: 341-345.

Winden J. V. D., Bogaerts S., 1992. Herpetofauna of the Göksu Delta Turkey. Report 311, Department of Animal Ecology Univ. Of Nijmegen, The Netherlands, 144p.

Yılmaz N., Tosunoğlu M., 2010. Hematology and Some Plasma Biochemistry Values of Free-Living Freshwater Turtles (Emys orbicularis and Mauremys rivulata) from Turkey. North-Western Journal of Zoology,6 (1): 109-117. 